\title{
Influence of Seed Processing and Storage on Seed Quality of Soybean Var. DSb-21
}

\author{
Vishwanath, Ravi Hunje*, R. Gurumurthy and M.V. Manjunatha \\ Department of Seed Science and Technology, University of Agricultural Sciences, \\ Dharwad-580005, Karnataka, India \\ *Corresponding author
}

\section{A B S T R A C T}

\section{Keywords}

Mechanical damage, Soybean var. DSb 21,

Processing, Sieve size, Seed recovery $(\%)$

Article Info

Accepted: 12 December 2018 Available Online: 10 January 2019
The influence of seed processing and storage on seed quality parameters were evaluated in soybean var. DSb-21 using different sieve size in seed grader followed by different machine combinations. The study revealed that graded seeds obtained from the sieve 3.75 $\mathrm{mm}$ followed by spiral separator recorded the higher recovery $(95.25 \%)$, germination $(88.33 \%$ and $68.33 \%)$, and vigour index (3502 and 1317) during initial and at ten months of storage period respectively. Seed processed through seed grader recorded higher recovery but lower in seed quality parameters. Seeds obtained from spiral separator after processing through seed grader followed by specific gravity separator has recorded higher seed quality parameters but lowest recovery per cent. Irrespective of processing methods followed, size graded seeds with $3.75 \mathrm{~mm}$ sieve maintained seed quality for more than eight months compare to seeds graded with $4.00 \mathrm{~mm}$ and $4.80 \mathrm{~mm}$ sieves. Processing of soybean seeds with seed grader followed by spiral separator can be recommended as it results in higher recovery with good seed quality parameters and the seeds maintained viability up to nine months of storage. Hence, grading soybean var. DSb-21 with $3.75 \mathrm{~mm}$ sieve is more effective and economical than presently recommended $4.0 \mathrm{~mm}$ sieve.

\section{Introduction}

Soybean [Glycine $\max (\mathrm{L}$.$) Merrill] is a major$ oil seed crop of the world grown in India. The crop is also called as "Golden Bean" or "Miracle crop" of the $21^{\text {st }}$ century on account of its multiple uses. It has the highest protein (40 \%) and rich oil (20\%), lysine and vitamins $\mathrm{A}, \mathrm{B}$ and $\mathrm{D}$. It is also rich source of minerals and essential amino acids. One of the major problems encountered in soybean production is lack of good quality seeds. The poor quality seeds maybe due to poor handling of seed during postharvest operating leading to poor and erratic field emergence and failure of seedling establishment in the field which subsequently results into low productivity. Uniformity in size and constituents of seed lot were emphasized for precision sowing as well as better crop establishment (Bishaw and Vangastel, 1996).

Mechanical seed processing improves physical purity as well as grade the seed according to 
size and specific gravity. This also improves the test weight, germination and vigour. Postharvest processing machineries and their adjustments affected seed quality in soybean and most of the seed crops like chickpea (Sinha et al., 2009), green gram, black gram, soybean, sunflower (Bansal and Lohan, 2009). The soybean seed varies greatly in size among different cultivars and within each cultivar. Uniformity of size in soybean seed allows the correct adjustment of the plant population in the field. At present the sieve size of $4.0 \mathrm{~mm}$ has been suggested by Seed Certification Agency to process the soybean seeds and it is based on old varieties. It is often observed that the seed growers are losing considerable quantity of good seed which is treated as a rejection.

At present routinely used seed processing machine for processing of soybean is seed grading machine (Air screen cleaner). Use of different machineries in combination helps in getting physically pure, uniform and healthy sound seeds. Hence an effort was made to study and find out the effective and economical seed processing combination to get maximum recovery with better quality of seed. Since seed coat of soybean is very thin and low in lignin content, it provides little protection to the fragile radicle which lies in a vulnerable position directly beneath the seed coat. Due to this fact, mechanical damage is one of the causes of great loss in soybean seed quality during harvest and processing (Franca Neto and Henning, 1984). Hence an experiment was under taken to find out effective machine combination for improving seed quality and storability.

\section{Materials and Methods}

The laboratory experiment was conducted to study the influence of seed processing and storage on seed quality parameters in soybean var. DSb-21 using different sieve sizes in seed grader followed by different machine combinations viz., $\mathrm{T}_{1}$ : Good seeds from seed grader after processing through recommended sieve size $-4.00 \mathrm{~mm}, \mathrm{~T}_{2}$ : Good seeds from seed grader after processing through below recommended sieve size $-3.75 \mathrm{~mm}, \mathrm{~T}_{3}$ : Good seeds from seed grader after processing through above recommended sieve size -4.80 $\mathrm{mm}, \mathrm{T}_{4}$ : Good seeds obtained from specific gravity separator after processing through seed grader from recommended sieve size - 4.00 $\mathrm{mm}$ (Heavy), $\mathrm{T}_{5}$ : Good seeds obtained from specific gravity separator after processing through seed grader from below recommended sieve size - $3.75 \mathrm{~mm}$ (Heavy), $\mathrm{T}_{6}$ : Good seeds obtained from specific gravity separator after processing through seed grader from above recommended sieve size - $4.80 \mathrm{~mm}$ (Heavy), $\mathrm{T}_{7}$ : Good seeds obtained from spiral separator after processed through seeds grader from recommended sieve size $-4.00 \mathrm{~mm}, \mathrm{~T}_{8}$ : Good seeds obtained from spiral separator after processed through seeds grader from below recommended sieve size $-3.75 \mathrm{~mm}, \mathrm{~T}_{9}$ : Good seeds obtained from spiral separator after processed through seeds grader from above recommended sieve size $-4.80 \mathrm{~mm}, \mathrm{~T}_{10}$ : Good seeds obtained from spiral separator after processing through seed grader from recommended sieve size $-4.00 \mathrm{~mm}$, followed by specific gravity separator, $\mathrm{T}_{11}$ : Good seeds obtained from spiral separator after processing through seed grader from below recommended sieve size $-3.75 \mathrm{~mm}$, followed by specific gravity separator, $\mathrm{T}_{12}$ : Good seeds obtained from spiral separator after processing through seed grader from above recommended sieve size $-4.80 \mathrm{~mm}$. followed by specific gravity separator and $\mathrm{T}_{13}$ : Unprocessed seeds (Bulk seed) as control at Seed Processing unit. Seeds obtained after size grading with different sieve sizes were collected and stored as per treatments under ambient conditions in High Density Polythene Bag. The seeds that retained on the screen were collected separately and there quality parameters were 
evaluated at Seed Quality and Research Laboratory, National Seeds Project, University of Agricultural Sciences, Dharwad during 2017-18.

The Seed germination percentage was worked out as per the procedure given by ISTA (Anon., 2011), seedling vigour index was worked out as per the formula given by Abdul-Baki and Anderson (1973), electrical conductivity of seed leachate by Presley (1958), Mechanical damage was worked out as per the procedure given by Mc. Donald (1985) and Seed recovery percentage was determined by using the following formula and expressed in percentage.

\begin{tabular}{ll} 
Seed & $\begin{array}{l}\text { Weight of seeds } \\
\text { obtained after } \\
\text { processing }\end{array}$ \\
\cline { 2 - 2 }$(\%)=$ & $\begin{array}{l}\text { Weight of seeds } \\
\text { before processing }\end{array}$
\end{tabular}

The data of the laboratory experiment were analyzed statistically by the procedure prescribed by Gomez and Gomez (2010).

\section{Results and Discussion}

During processing with different machine combinations physically pure, healthy sound seeds with uniformity in seed size, shape, weight, and roundness with negligible impurities were obtained. Seed recovery and mechanical damage per cent as affected by processing methods are depicted in figure 1 and 2 respectively.

The germination percentage of soybean declined progressively with the advancement in storage period. On an average the germination percentage recorded at the beginning and at the end of storage period was 84.36 and 65.69 per cent, respectively. A significant difference in germination percentage due to seed grading, specific gravity and spiral separator was observed throughout the storage period. Significantly higher germination percentage was recorded in $\mathrm{T}_{11}$ [seeds obtained from spiral separator after processing through seed grader from below recommended sieve size - $3.75 \mathrm{~mm}$, followed by specific gravity separator $(89.00$ $\%$ )] (Table 1), which is on par with $\mathrm{T}_{8}$ [seeds obtained from spiral separator after processed through seed grader from below recommended sieve size - $3.75 \mathrm{~mm}(88.33 \%)$ ], $\mathrm{T}_{10}$ [seeds obtained from spiral separator after processing through seed grader from recommended sieve size $-4.00 \mathrm{~mm}$, followed by specific gravity separator $(87.33 \%)$ ] and $\mathrm{T}_{7}$ seeds obtained from spiral separator after processed through seed grader from recommended sieve size $4.00 \mathrm{~mm}(86.00 \%)$ during initial storage period.

Significantly higher germination percentage was recorded at end of storage period in $\mathrm{T}_{8}$ [seeds obtained from spiral separator after processed through seed grader from below recommended sieve size - $3.75 \mathrm{~mm}(68.33 \%)$ ] which is on par with $\mathrm{T}_{1}(66.67 \%), \mathrm{T}_{2}$ (67.67\%), $\quad \mathrm{T}_{4}(67.00 \%), \mathrm{T}_{5}(68.00 \%), \mathrm{T}_{6}$ $(66.67 \%), \mathrm{T}_{7}(67.33 \%), \mathrm{T}_{9}(66.00 \%)$ and $\mathrm{T}_{11}$ (65.67\%). Significantly lowest seed germination was recorded throughout the storage period in $\mathrm{T}_{13}$ (unprocessed seeds), which recorded a germination percentage of 77.33 and 55.33 during initial and at the end of $10^{\text {th }}$ month of storage period respectively.

Germination percentage was high in $T_{11}$ during initial storage period even though mechanical damage (in many cases mechanical damage was observed for seed coat and less affected to embryonic part) was more $(11.67 \%)$, as seed quality were assessed immediately after processing further there was less chance of mycoflora infection. Germination declined rapidly in $T_{11}$ along the storage period as mechanical damaged seeds are more vulnerable to the attack by mycoflora 
and lost viability quickly. Higher Germination was maintained in $\mathrm{T}_{8}$ up to nine months which may be due to less mechanical damage (9.0 $\%$ ) and more physical purity. During storage, the injured or deeply bruised areas may serve as centers for infection and result in deterioration of seeds. Injuries close to vital parts of embryonic axis or near the point of attachment of cotyledons to the axis usually bring about the most rapid losses of viability (Bewley and Black, 1984). Mechanically damaged or broken seed coats permit early entry and easy access for mycoflora to enter in to the seeds. Broken or cracked seed coats also enhance embryo damage by chemical treatment including chemicals used for disinfectant. Both the fungi and chemical damage reduce the keeping quality of stored seeds. The low germination per cent was mainly due to occurrence of high percentage of abnormal seedlings. The abnormality was due to presence of scars on more than half of the cotyledons thus making it nonphotosynthetic area and split hypocotyls. The presence of scar and split hypocotyls suggested that the seeds either had received natural damage or mechanical injury or both.

Differences in shoot length, root length and vigour index among the processed seeds may be due to the difference in seed size and extent of mechanical injury. A small-seeded variant of Lee had better germination, greater early hypocotyl development and lower leakage of sugars than the large-seeded type (Gupta 1976). Mechanical damage to the seed may be one of the causes for reduction in length of seedlings of soybean. The processing methods produce breaks, cracks, bruises and abrasions in seeds which in turn results in abnormal seedlings of questionable planting value. It is obvious from the available information that mechanical injury to seeds not only reduces production of normal seedlings but also decreases the storage potential of damaged seed that apparently would have produced normal seedlings prior to storage; these results are in conformity with the findings of Kausal et al., (1991).

The seedling vigour index-I of soybean declined progressively with the enhanced storage period. On an average the seedling vigour index-I recorded at the beginning and at the end of storage period was 3214 and 1136 respectively. A significant difference in seedling vigour index-I due to seed grading, specific gravity and spiral separator was observed throughout the storage period. Significantly higher seedling vigour index-I was recorded in $T_{11}$ [seeds obtained from spiral separator after processing through seed grader from below recommended sieve size $3.75 \mathrm{~mm}$, followed by specific gravity separator (3567)] (Table 2), which is on par with $\mathrm{T}_{8}$ [seeds obtained from spiral separator after processed through seed grader from below recommended sieve size $-3.75 \mathrm{~mm}$ (3502)] during initial storage period.

Significantly higher seedling vigour index-I was recorded at end of storage period in $T_{8}$ [seeds obtained from spiral separator after processed through seed grader from below recommended sieve size - $3.75 \mathrm{~mm}$ (1317)] which is on par with $\mathrm{T}_{5}$ (1269) and $\mathrm{T}_{2}$ (1268). Significantly lowest seedling vigour index-I was recorded throughout the storage period in $\mathrm{T}_{13}$ (unprocessed seeds), which recorded a seedling vigour index-I of 2764 and 847 during initial and at the end of $10^{\text {th }}$ month of storage period respectively. It was observed that seedling length and vigour index I was decreased as the storage period advanced. The decrease in length of seedlings could be due to the ageing or deterioration of seed, which is progressive process, accompanied by accumulation of metabolites and progressively decreases germination and growth of seedlings with increased age (Floris, 1970) and ultimately vigour of soybean seed during storage. 
Table.1 Influence of seed grading, specific gravity separator and spiral separator on germination (\%) of soybean during storage

\begin{tabular}{|c|c|c|c|c|c|c|c|c|c|c|c|}
\hline \multicolumn{12}{|c|}{ Months of storage } \\
\hline Treatments & Initial & First & Second & Third & Fourth & Fifth & Sixth & Seventh & Eighth & Ninth & Tenth \\
\hline $\mathrm{T}_{1}$ & 83.33 & 82.00 & 81.00 & 78.00 & 75.67 & 74.00 & 72.67 & 71.33 & 70.00 & 68.00 & 66.67 \\
\hline $\mathbf{T}_{2}$ & 84.33 & 83.33 & 82.67 & 78.67 & 76.67 & 75.67 & 74.00 & 72.33 & 71.00 & 69.00 & 67.67 \\
\hline $\mathbf{T}_{3}$ & 81.33 & 80.00 & 79.33 & 76.67 & 74.33 & 73.33 & 71.67 & 69.67 & 69.00 & 66.67 & 65.33 \\
\hline $\mathbf{T}_{4}$ & 84.33 & 83.67 & 82.67 & 79.33 & 77.67 & 74.67 & 73.33 & 71.67 & 70.33 & 68.33 & 67.00 \\
\hline $\mathbf{T}_{5}$ & 85.00 & 84.33 & 83.67 & 80.33 & 79.00 & 76.00 & 74.33 & 73.00 & 71.67 & 69.00 & 68.00 \\
\hline $\mathbf{T}_{6}$ & 81.67 & 80.00 & 78.67 & 77.33 & 75.67 & 74.33 & 72.00 & 70.00 & 69.33 & 67.00 & 66.67 \\
\hline $\mathbf{T}_{7}$ & 86.00 & 84.33 & 82.67 & 80.00 & 77.67 & 76.00 & 74.33 & 72.00 & 71.67 & 69.33 & 67.33 \\
\hline $\mathbf{T}_{8}$ & 88.33 & 86.33 & 84.00 & 81.33 & 79.67 & 77.67 & 75.67 & 73.33 & 72.33 & 70.00 & 68.33 \\
\hline $\mathbf{T}_{9}$ & 83.67 & 83.33 & 81.67 & 78.33 & 76.33 & 74.33 & 73.00 & 71.00 & 70.33 & 68.00 & 66.00 \\
\hline $\mathbf{T}_{10}$ & 87.33 & 86.00 & 85.33 & 81.67 & 79.33 & 76.67 & 75.33 & 72.67 & 70.33 & 68.00 & 65.33 \\
\hline $\mathbf{T}_{11}$ & 89.00 & 87.67 & 86.33 & 82.33 & 80.67 & 78.00 & 76.33 & 73.67 & 71.00 & 68.33 & 65.67 \\
\hline $\mathbf{T}_{12}$ & 85.00 & 83.67 & 82.00 & 79.67 & 77.67 & 75.67 & 74.00 & 71.67 & 69.33 & 67.00 & 64.67 \\
\hline $\mathbf{T}_{13}$ & 77.33 & 76.33 & 75.00 & 73.67 & 71.00 & 69.67 & 68.33 & 65.67 & 61.33 & 58.67 & 55.33 \\
\hline Mean & 84.36 & 83.15 & 81.92 & 79.03 & 77.03 & 75.08 & 73.46 & 71.38 & 69.82 & 67.51 & 65.69 \\
\hline S. Em. \pm & 0.91 & 0.93 & 0.85 & 1.07 & 0.84 & 0.82 & 0.62 & 0.78 & 0.64 & 0.88 & 0.88 \\
\hline C.D. @ $1 \%$ & 2.63 & 2.71 & 2.46 & 3.11 & 2.45 & 2.37 & 1.80 & 2.28 & 1.86 & 2.55 & 2.56 \\
\hline
\end{tabular}

$\mathrm{T}_{1}$ : Good seeds from seed grader after processing through recommended sieve size $-4.00 \mathrm{~mm}$

$\mathrm{T}_{2}$ : Good seeds from seed grader after processing through below recommended sieve size $-3.75 \mathrm{~mm}$

$\mathrm{T}_{3}$ : Good seeds from seed grader after processing through above recommended sieve size $-4.80 \mathrm{~mm}$

$\mathrm{T}_{4}$ : Seeds obtained from specific gravity separator after processing through seed grader from recommended sieve size - $4.00 \mathrm{~mm}$ (Heavy)

$\mathrm{T}_{5}$ : Seeds obtained from specific gravity separator after processing through seed grader from below recommended sieve size - $3.75 \mathrm{~mm}$ (heavy)

$\mathrm{T}_{6}$ : Seeds obtained from specific gravity separator after processing through seed grader from above recommended sieve size - $4.80 \mathrm{~mm}$ (Heavy)

$\mathrm{T}_{7}$ : Good seeds obtained from spiral separator after processed through seed grader from recommended sieve size $-4.00 \mathrm{~mm}$.

$\mathrm{T}_{8}$ : Good seeds obtained from spiral separator after processed through seed grader from below recommended sieve size - $3.75 \mathrm{~mm}$.

$\mathrm{T}_{9}$ : Good seeds obtained from spiral separator after processed through seed grader from above recommended sieve size- $4.80 \mathrm{~mm}$.

$\mathrm{T}_{10}$ : Good seeds obtained from spiral separator after processing through seed grader from recommended sieve size - $4.00 \mathrm{~mm}$, followed by specific gravity separator.

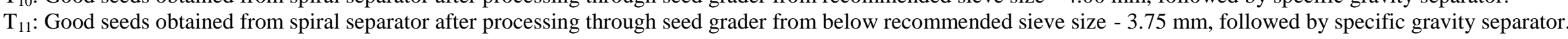

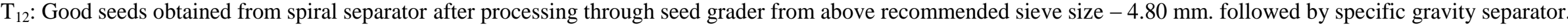

$\mathrm{T}_{13}$ : Unprocessed seeds (Bulk seed) control. 
Table.2 Influence of seed grading, specific gravity separator and spiral separator on seedling vigour index-I of soybean during storage

\begin{tabular}{|c|c|c|c|c|c|c|c|c|c|c|c|}
\hline \multicolumn{12}{|c|}{ Months of storage } \\
\hline Treatments & Initial & First & Second & Third & Fourth & Fifth & Sixth & Seventh & Eighth & Ninth & Tenth \\
\hline $\mathbf{T}_{1}$ & 3138 & 2937 & 2658 & 2399 & 2164 & 1963 & 1782 & 1598 & 1453 & 1287 & 1134 \\
\hline $\mathbf{T}_{2}$ & 3237 & 3069 & 2820 & 2537 & 2307 & 2124 & 1939 & 1731 & 1576 & 1420 & 1268 \\
\hline $\mathbf{T}_{\mathbf{3}}$ & 2974 & 2737 & 2522 & 2265 & 2055 & 1884 & 1688 & 1484 & 1365 & 1199 & 1026 \\
\hline $\mathbf{T}_{4}$ & 3180 & 2995 & 2773 & 2457 & 2241 & 1975 & 1818 & 1621 & 1465 & 1298 & 1148 \\
\hline $\mathbf{T}_{5}$ & 3294 & 3152 & 2928 & 2616 & 2386 & 2137 & 1952 & 1756 & 1592 & 1413 & 1269 \\
\hline $\mathbf{T}_{6}$ & 3017 & 2757 & 2513 & 2315 & 2112 & 1912 & 1709 & 1507 & 1376 & 1206 & 1057 \\
\hline $\mathbf{T}_{7}$ & 3358 & 3074 & 2757 & 2506 & 2267 & 2031 & 1851 & 1654 & 1589 & 1414 & 1248 \\
\hline $\mathbf{T}_{8}$ & 3502 & 3269 & 2933 & 2652 & 2426 & 2184 & 1983 & 1788 & 1644 & 1470 & 1317 \\
\hline $\mathbf{T}_{9}$ & 3129 & 2896 & 2644 & 2367 & 2143 & 1925 & 1739 & 1551 & 1418 & 1251 & 1066 \\
\hline $\mathbf{T}_{10}$ & 3418 & 3167 & 2939 & 2694 & 2424 & 2148 & 1948 & 1714 & 1464 & 1318 & 1158 \\
\hline $\mathbf{T}_{11}$ & 3567 & 3368 & 3087 & 2864 & 2581 & 2298 & 2037 & 1781 & 1569 & 1375 & 1207 \\
\hline $\mathbf{T}_{12}$ & 3209 & 2941 & 2708 & 2422 & 2168 & 1919 & 1723 & 1534 & 1342 & 1204 & 1022 \\
\hline $\mathbf{T}_{13}$ & 2764 & 2575 & 2332 & 2124 & 1903 & 1728 & 1572 & 1367 & 1166 & 1020 & 847 \\
\hline Mean & 3214 & 2995 & 2740 & 2478 & 2244 & 2018 & 1826 & 1622 & 1463 & 1299 & 1136 \\
\hline S. Em. \pm & 39 & 30 & 30 & 40 & 31 & 18 & 24 & 29 & 24 & 26 & 21 \\
\hline C.D. @ $1 \%$ & 114 & 88 & 87 & 117 & 89 & 53 & 69 & 85 & 71 & 75 & 61 \\
\hline
\end{tabular}

$\mathrm{T}_{1}$ : Good seeds from seed grader after processing through recommended sieve size $-4.00 \mathrm{~mm}$

$\mathrm{T}_{2}$ : Good seeds from seed grader after processing through below recommended sieve size $-3.75 \mathrm{~mm}$

$\mathrm{T}_{3}$ : Good seeds from seed grader after processing through above recommended sieve size $-4.80 \mathrm{~mm}$

$\mathrm{T}_{4}$ : Seeds obtained from specific gravity separator after processing through seed grader from recommended sieve size - $4.00 \mathrm{~mm}$ (Heavy)

$\mathrm{T}_{5}$ : Seeds obtained from specific gravity separator after processing through seed grader from below recommended sieve size - $3.75 \mathrm{~mm}$ (heavy)

$\mathrm{T}_{6}$ : Seeds obtained from specific gravity separator after processing through seed grader from above recommended sieve size - $4.80 \mathrm{~mm}$ (Heavy)

$\mathrm{T}_{7}$ : Good seeds obtained from spiral separator after processed through seed grader from recommended sieve size $-4.00 \mathrm{~mm}$.

$\mathrm{T}_{8}$ : Good seeds obtained from spiral separator after processed through seed grader from below recommended sieve size - $3.75 \mathrm{~mm}$.

$\mathrm{T}_{9}$ : Good seeds obtained from spiral separator after processed through seed grader from above recommended sieve size- $4.80 \mathrm{~mm}$.

$\mathrm{T}_{10}$ : Good seeds obtained from spiral separator after processing through seed grader from recommended sieve size - $4.00 \mathrm{~mm}$, followed by specific gravity separator.

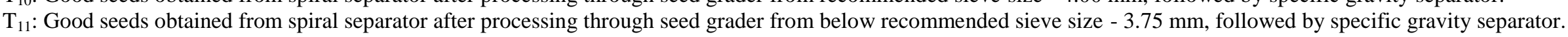

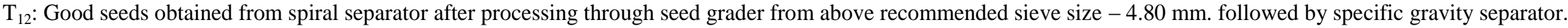

$\mathrm{T}_{13}$ : Unprocessed seeds (Bulk seed) control. 
Table.3 Influence of seed grading, specific gravity separator and spiral separator on electrical conductivity $\left(\mathrm{dS} \mathrm{m}^{-1}\right)$ of soybean during storage

\begin{tabular}{|c|c|c|c|c|c|c|c|c|c|c|c|}
\hline \multicolumn{12}{|c|}{ Months of storage } \\
\hline Treatments & Initial & First & Second & Third & Fourth & Fifth & Sixth & Seventh & Eighth & Ninth & Tenth \\
\hline $\mathrm{T}_{1}$ & 0.744 & 0.802 & 0.888 & 1.065 & 1.232 & 1.342 & 1.445 & 1.555 & 1.668 & 1.793 & 1.919 \\
\hline $\mathbf{T}_{2}$ & 0.727 & 0.775 & 0.852 & 0.986 & 1.134 & 1.226 & 1.317 & 1.409 & 1.505 & 1.616 & 1.726 \\
\hline $\mathbf{T}_{\mathbf{3}}$ & 0.766 & 0.845 & 0.953 & 1.148 & 1.353 & 1.489 & 1.625 & 1.761 & 1.901 & 2.055 & 2.210 \\
\hline $\mathbf{T}_{4}$ & 0.793 & 0.860 & 0.953 & 1.057 & 1.169 & 1.273 & 1.357 & 1.381 & 1.479 & 1.589 & 1.700 \\
\hline $\mathbf{T}_{5}$ & 0.780 & 0.837 & 0.920 & 1.014 & 1.126 & 1.220 & 1.310 & 1.316 & 1.405 & 1.507 & 1.608 \\
\hline $\mathbf{T}_{6}$ & 0.802 & 0.889 & 1.002 & 1.126 & 1.332 & 1.456 & 1.596 & 1.612 & 1.734 & 1.870 & 2.005 \\
\hline $\mathbf{T}_{7}$ & 0.727 & 0.783 & 0.866 & 0.960 & 1.099 & 1.193 & 1.278 & 1.372 & 1.467 & 1.574 & 1.682 \\
\hline $\mathbf{T}_{8}$ & 0.715 & 0.762 & 0.835 & 0.919 & 1.040 & 1.124 & 1.199 & 1.283 & 1.368 & 1.467 & 1.565 \\
\hline $\mathbf{T}_{9}$ & 0.748 & 0.825 & 0.928 & 1.042 & 1.217 & 1.331 & 1.430 & 1.544 & 1.657 & 1.783 & 1.908 \\
\hline $\mathbf{T}_{10}$ & 0.787 & 0.856 & 0.955 & 0.985 & 1.101 & 1.198 & 1.284 & 1.461 & 1.563 & 1.675 & 1.788 \\
\hline $\mathbf{T}_{11}$ & 0.757 & 0.813 & 0.894 & 0.940 & 1.063 & 1.151 & 1.228 & 1.404 & 1.500 & 1.611 & 1.721 \\
\hline $\mathbf{T}_{12}$ & 0.803 & 0.887 & 1.012 & 1.072 & 1.260 & 1.379 & 1.493 & 1.720 & 1.853 & 2.004 & 2.154 \\
\hline $\mathbf{T}_{13}$ & 0.788 & 0.956 & 1.107 & 1.269 & 1.640 & 1.802 & 1.964 & 2.126 & 2.292 & 2.472 & 2.653 \\
\hline Mean & 0.764 & 0.838 & 0.936 & 1.045 & 1.213 & 1.322 & 1.425 & 1.534 & 1.646 & 1.770 & 1.895 \\
\hline S. Em. \pm & 0.009 & 0.012 & 0.012 & 0.012 & 0.019 & 0.019 & 0.019 & 0.019 & 0.019 & 0.019 & 0.019 \\
\hline C.D. @ $1 \%$ & 0.026 & 0.034 & 0.034 & 0.034 & 0.055 & 0.055 & 0.055 & 0.055 & 0.056 & 0.056 & 0.056 \\
\hline
\end{tabular}

$\mathrm{T}_{1}$ : Good seeds from seed grader after processing through recommended sieve size $-4.00 \mathrm{~mm}$

$\mathrm{T}_{2}$ : Good seeds from seed grader after processing through below recommended sieve size $-3.75 \mathrm{~mm}$

$\mathrm{T}_{3}$ : Good seeds from seed grader after processing through above recommended sieve size- $4.80 \mathrm{~mm}$

$\mathrm{T}_{4}$ : Seeds obtained from specific gravity separator after processing through seed grader from recommended sieve size - $4.00 \mathrm{~mm}$ (Heavy)

$\mathrm{T}_{5}$ : Seeds obtained from specific gravity separator after processing through seed grader from below recommended sieve size - 3.75 mm (heavy)

$\mathrm{T}_{6}$ : Seeds obtained from specific gravity separator after processing through seed grader from above recommended sieve size - $4.80 \mathrm{~mm}$ (Heavy)

$\mathrm{T}_{7}$ : Good seeds obtained from spiral separator after processed through seed grader from recommended sieve size $-4.00 \mathrm{~mm}$.

$\mathrm{T}_{8}$ : Good seeds obtained from spiral separator after processed through seed grader from below recommended sieve size - $3.75 \mathrm{~mm}$.

$\mathrm{T}_{9}$ : Good seeds obtained from spiral separator after processed through seed grader from above recommended sieve size- $4.80 \mathrm{~mm}$.

$\mathrm{T}_{10}$ : Good seeds obtained from spiral separator after processing through seed grader from recommended sieve size - 4.00 mm, followed by specific gravity separator.

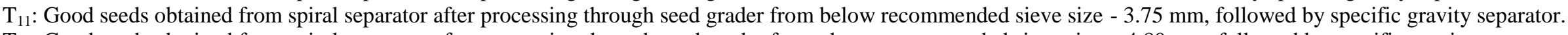

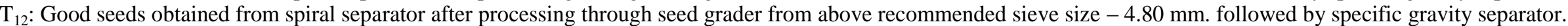

$\mathrm{T}_{13}$ : Unprocessed seeds (Bulk seed) control. 
Fig.1 Influence of seed processing on seed recovery of soybean

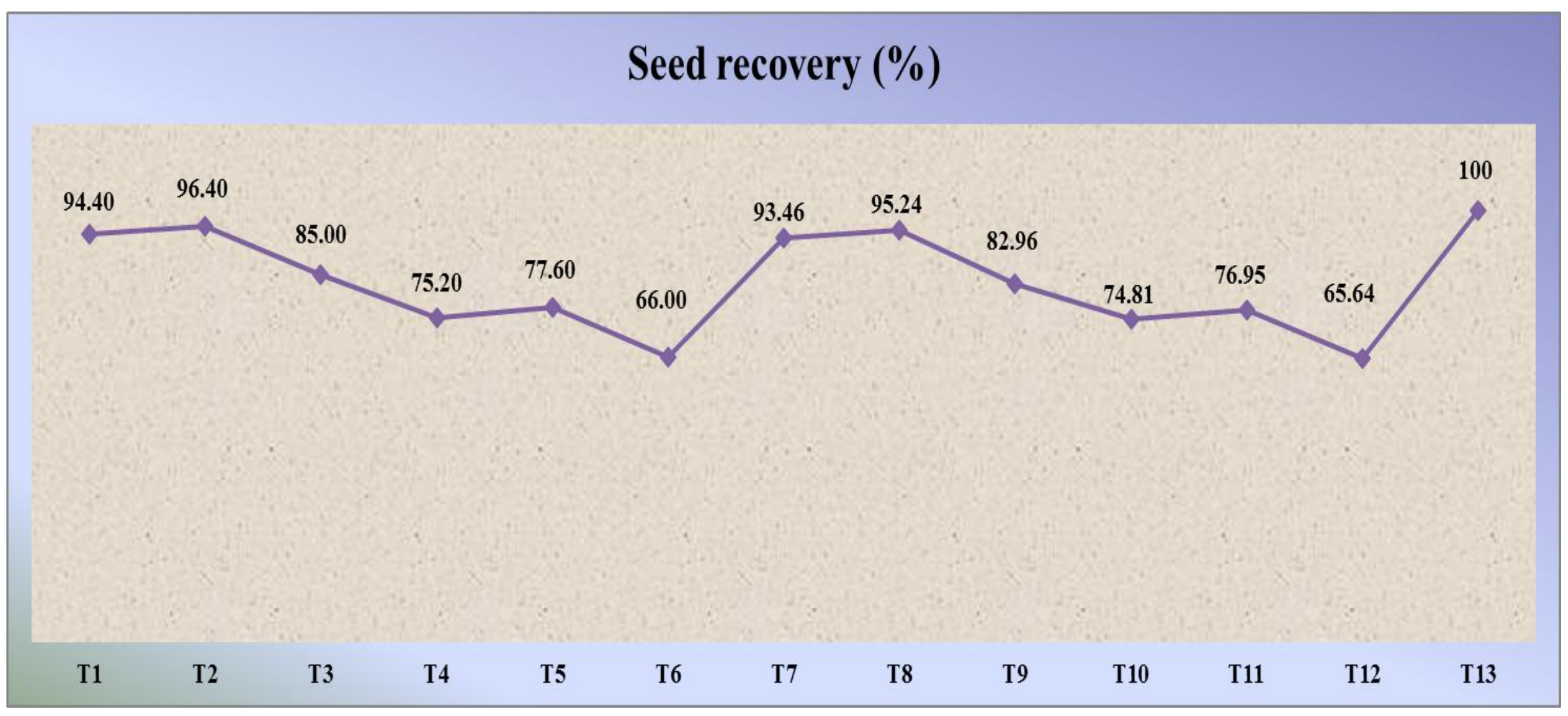


Fig.2 Influence of seed processing on mechanical damage of soybean during storage

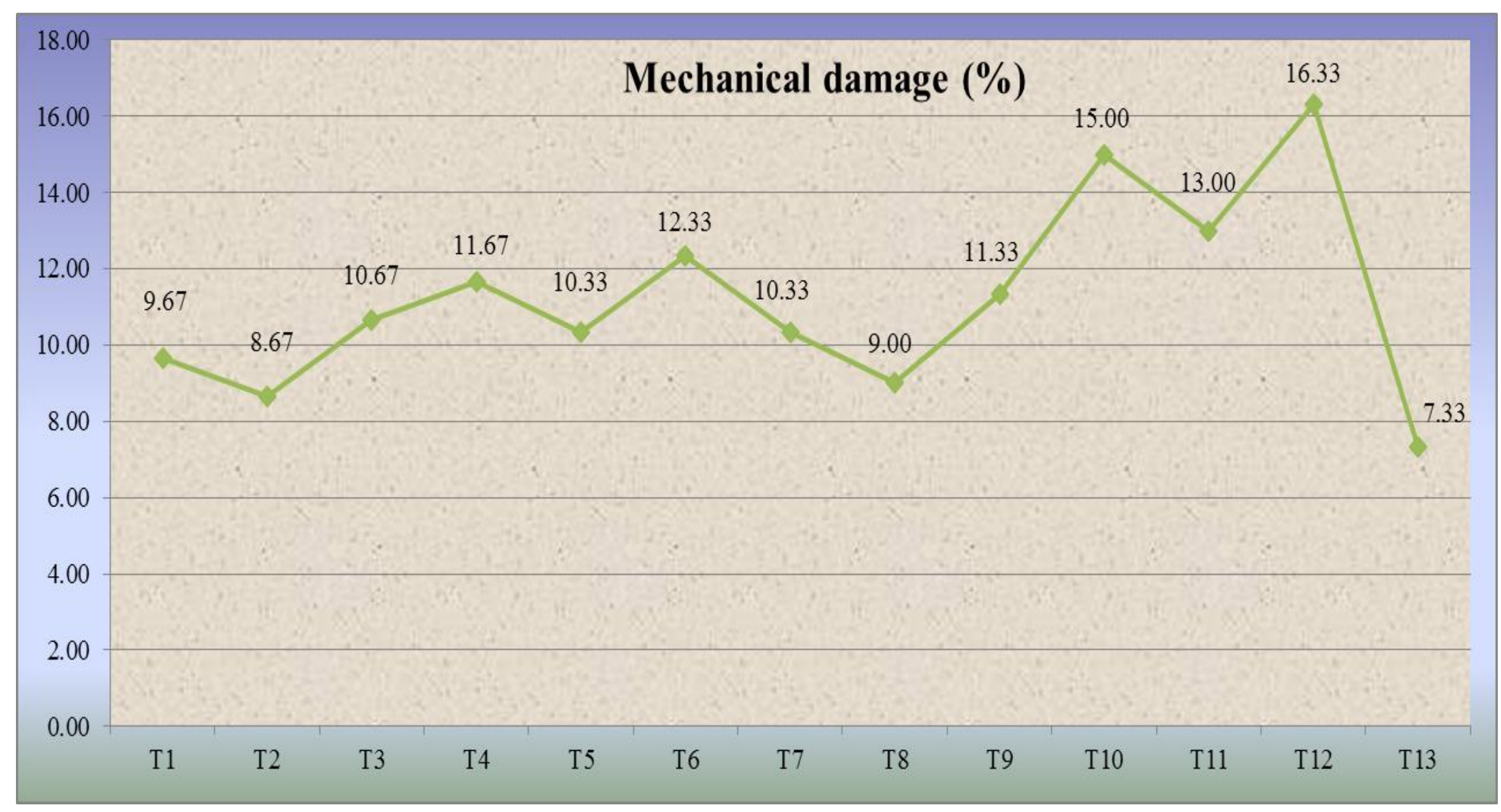


Seedling growth is considered to be an important tool that can be used for assessing the magnitude of deterioration (Toole et al., 1957). Relative poor growth in terms of radicle, hypocotyls and leaf length was observed in highly deteriorated lots (Srivastava and Gill, 1975) resulting in low vigour as seed deteriorated during storage.

The vigour index was found to be gradually decreased with advancement of storage period. The vigour of the seeds at the time of storage is an important factor that affected their storage life. Most seeds are physiologically mature at this point. When physiologically matures, the seed possesses its greatest vigour. From this point, it gradually loses vigour and eventually dies. The rate in decline is conditioned by several factors, including genetic constitution of the species or cultivar, condition of the seed, storage condition, and uniformity of seed lot. Loss of vigour can be thought as an intermediate stage in the life of the seed, occurring between the onset and termination of death. Trawartha et al., (1995) reported that seed vigour and viability declined during storage. A seedling cotyledon necrosis emerges at slower rate and had lower seedling dry weight. Similar results of decrease in vigour were reported by Duke et al., (1983).

A significant difference in electrical conductivity due to seed grading, specific gravity and spiral separator was observed throughout the storage period. Significantly lower electrical conductivity was recorded in $\mathrm{T}_{8}$ [Seeds obtained from Spiral separator after processed through seeds grader from below recommended sieve size $-3.75 \mathrm{~mm}(0.715 \mathrm{dS}$ $\mathrm{m}^{-1}$ )] (Table 3), which is on par with $\mathrm{T}_{2}$ [Good seeds from seed grader after processing through below recommended sieve size $-3.75 \mathrm{~mm}$ $\left(0.727 \mathrm{dS} \mathrm{m}^{-1}\right)$ ], and $\mathrm{T}_{7}$ [Seeds obtained from spiral separator after processed through seeds grader from recommended sieve size $-4.00 \mathrm{~mm}$ $\left.\left(0.727 \mathrm{dS} \mathrm{m}^{-1}\right)\right]$ and significantly higher electrical conductivity was recorded in $T_{12}$ $\left(0.803 \mathrm{dS} \mathrm{m}^{-1}\right)$.
Significantly higher electrical conductivity was recorded at end of storage period in $T_{13}$ [unprocessed seeds $\left(2.653\right.$ dS $\left.\mathrm{m}^{-1}\right)$ ]. Significantly lowest electrical conductivity was recorded throughout the storage period in, $\mathrm{T}_{8}$ [seeds obtained from spiral separator after processed through seed grader from below recommended sieve size - $3.75 \mathrm{~mm}$ ] which recorded an electrical conductivity of 0.715 and $1.565 \mathrm{dS} \mathrm{m}^{-1}$ during initial and at the end of $10^{\text {th }}$ month of storage period respectively.

The electrical conductivity of soybean increased progressively with the advancement in storage period. A significant difference in electrical conductivity due to processing methods was observed throughout the storage period. The electrical conductivity increased with subsequent increase in storage period irrespective of processing methods. Lower electrical conductivity in $\mathrm{T}_{8}$ may be due to smaller seed size, less mechanical damage and more physical purity thus less attach by mycoflora. Increase in electrical conductivity along storage period might be caused by increase in permeability of membrane of deteriorated seed. Loss of membrane integrity of deteriorated seeds leaks more substances into the medium. This could be attributed to the high mechanical injury, poor membrane structure and leaky cells. These results in greater loss of electrolytes such as sugars, amino and organic acids from seeds and increased conductivity in the soak water (Abdul Baki and Anderson, 1973; Agrawal, 1977).

It is conclusion, among the processed and stored seeds, seeds obtained from spiral separator after processing through seed grader from below recommended sieve size $3.75 \mathrm{~mm}$, recorded higher seed quality parameters i.e. germination, seedling vigour index-I and lower electrical conductivity of seed leachates along the storage period and they maintained $70 \%$ (MSCS) germination up to nine months of storage period. Processing of soybean seeds with seed grader followed by spiral separator can be recommended as it results in higher recovery with good seed quality parameters and the seeds 
maintained viability up to nine months of storage.

\section{References}

Abdul Baki, A. A. and Anderson, J. D. 1973. Vigour determination in soybean seed by multiple criteria. Crop Science. 13: 630633.

Agarwal, P. K. and Siddiqui, M. N., 1977. Influence of storage temperature and seed moisture on germination, free fatty acid content and leaching of sugars of soybean seeds during storage. Seed Research. 1:7582.

Anonymous. 2011. International rules for seed testing (ISTA). Seed Science and Technology. 27: 175.

Bansal, N. K. and Lohan, S. K. 2009. Design and development of an axial flow thresher for seed crops. Journal of Agricultural Engineering. 46(1): 1-8.

Bewley, J. D. and Black, M. 1984. Seed: Physiology of development and germination. plenum press. New York and London. Pp- 97.

Bishaw, Z. and Vangastel, A. J. G. 1996. Components of seed quality. In: Proc. A train - the trainer's workshop. Pp- 289-298.

Duke, S. H., Kakefuda, G. and Harvey, T. M. 1983. Differential leakage of intracellular substance from imbibing soybean seeds. Plant Physiology. 72: 919-924.

Floris, C. 1970. Ageing in Triticum durum seeds: Behaviour of embryos and endosperm from aged seeds as revealed by the embryo transplantation technique. Journal Experimental Botany. 21: 462-468.

Franca Neto, J. B. and Henning, A. A. 1984. Qualidades fisiologica e sanitaria de sementes de soja. (Physiological and pathological qualities of soybean seeds) EMBRAPA National Soybean Research Centre, Londrina, Parana, Brazil. Circulartecnica. 09(39).

Gomez, K. A. and Gomez, Z. A. 1984. Statistical Procedures for Agricultural Research, A Wiley International Science Publication, New York.

Gupta, P. C. 1976. Viability of stored soybean seeds in India. Seed Research. 4 (1): 32-39.

Kausal, R. T., Jeughale, G. S., Kakade, S. U. and Pravitrakar, N. R. 1991. Studies on optimum sieve size and type of screen for grading soybean seed. International Journal of Agricultural Sciences. 4: 59-62.

Mc Donald, M. B. 1985. Physical seed quality of soybean. Seed Science and Technology. 13: 601-628.

Presley, J. J. 1958. Relations of protoplast permeability to cotton seed viability and predisposition of seedling disease. Plant Disease Report. 42: 5852.

Sinha, J. P., Dhaliwal, J. S., Sinha, S. N. 2009. Effect of machine parameters on threshing quality for seed crop in chick pea. Journal of Agricultural Engineering. 46(4): 11-16.

Srivastava, A. K. and Gill, M. K. 1975. Physiology and biochemistry of seed deterioration in soybean, part II seeding growth and leachate analysis. Indian Journal of Experimental Biology. 133: 481485.

Toole, E. H., Toole, V. K. and Borthwick, H. A. 1957. Growth and production of snap beans stored under favourable and unfavourable conditions. Proc. International Seed Testing Association. 22: 418.

Trawartha, S. E., Tekrony, D. M. and Hildebrand, D. F. 1995. Soybean lipoxygenase mutants and seed longevity. Crop Science. 35: 862868

\section{How to cite this article:}

Vishwanath, Ravi Hunje, R. Gurumurthy and Manjunatha, M.V. 2019. Influence of Seed Processing and Storage on Seed Quality of Soybean Var. DSb-21. Int.J.Curr.Microbiol.App.Sci. 8(01): 1684-1694. doi: https://doi.org/10.20546/ijcmas.2019.801.178 